\title{
Impact of Supply Chain Management Strategies and Practices in the Textile Retail Sector in Islamabad, Pakistan
}

\author{
Mehwish Naeem, Iram Tahir, Zain Iqbal, Hassaan Shafique
}

\begin{abstract}
This research was conducted to investigate the impact of supply chain management strategies and practices on the retail supply chain performance specifically focusing on textile or apparel industry. For Sample selection we chose systematic random sampling method and a list of 120 retail stores located in Islamabad was developed. Data was collected from every second store on the list using a survey questionnaire, giving a sample size of 60 managers of textile retail stores. The data accumulated was analyzed by performing different statistical tests, reliability, mean, correlation, standard deviation and regression. The findings showed that supply chain practices have an impact on retail supply chain performance statistically but, supply chain strategies do not have an impact on retail supply chain performance. However, supply chain strategies and practices are significantly related to each other.
\end{abstract}

Keywords: Supply chain management strategies, supply chain management practices and retail supply chain performance.

\section{INTRODUCTION}

In this globalized era, consistency in responsiveness to customers' predilections is a major obstacle being faced by most organizations. To provide better satisfaction to their customers, organizations are implementing different business strategies to absorb the change in this environment. One of the strategies that is being adopted and should be highlighted and investigated is the supply chain strategy. Supply chain strategies are one of the crucial strategies to be studied for increasing the performance of the supply chain (Hanson, Melynk, \& Calantonr, 2011). Additionally, we have also tried to examine the influence of supply chain practices on supply chain performance in this study. However, present studies available mostly focus on the manufacturing sector (Kazi \& Nazmul Ahsan, 2014). Therefore, research needs to be conducted in other industries and sectors with regards to supply chain. One area of focus is the retail or apparel sector, in which the influence of supply chain strategies on retail supply chain performance can be observed (Rana, Osman,

Revised Manuscript Received on September 22, 2019

* Correspondence Author

Mehwish Naeem, Shaheed Zulfikar Ali Bhutto Institute of Science and Technology (SZABIST), Islamabad, Pakistan. Email: mehwish_naeem84@hotmail.com

Iram Tahir*, Department of Public Administration, University of Karachi, Pakistan. Email: iramafzaltahir@gmail.com

Zain Iqbal, Shaheed Zulfikar Ali Bhutto Institute of Science and Technology (SZABIST), Islamabad, Pakistan. Email: zziqbal440@gmail.com

Hassaan Shafique, Shaheed Zulfikar Ali Bhutto Institute of Science and Technology (SZABIST), Islamabad, Pakistan. Email: hassaan_shafique@yahoo.com

Bahari, \& Solaiman, 2015). Our study's main research objective is to investigate the influence of supply chain strategies and practices on the performance of retail supply chain.

\section{LITERATURE REVIEW}

\section{A. Supply Chain Strategy}

Supply chain strategies deal with issues, from acquisition of raw material, operations, production, manufacturing finished goods or services, conveyance and delivery, to and from all supply chain members including company, manufacturers or producers, suppliers, distributors and customers as well as maintenance and follow up services, be it out-sourced or in-house (Qi et al., 2011). The retailers supply chain management strategy refers to strategic targets, aims and objectives defined by the retailers in light of their supply chain (Rana et al., 2015). (Naylor, Naim, \& Berry, 1999; Towill \& Christopher, 2002) proposed three supply chain management strategies that influence supply chain performance i.e. agile, lean and hybrid strategy.

The objective of an agile strategy is to be flexible and responsive to changing customer needs (Jacobs \& Chase, 2008; H. Lee, 2002b). This strategy is most suitable for products whose demand nature is uncertain (Ayers, 2006; Seuring, Goldbach, Schneidewind, \& Muller, 2003; Towill \& Christopher, 2002) and is used in instances where time compression and quick response are a priority as it assists in removing barriers from responsiveness (Christopher, 2003).

The lean strategy is implemented when the goal is to minimize expense and wastage (Vitasek, Manrodt, \& Abbott, 2005). This is accomplished through removing all activities that do not add value, implementing scale of economies, optimizations systems and practices to attain optimal capacity utilization for production to delivery (Jacobs \& Chase, 2008; H. Lee, 2002).

When organizations requirements equally need agile and lean supply chains they implement a hybrid supply chain (Towill \& Christopher, 2002). Hybrid (also known as leagile) supply chain utilizes a framework that follows both the approaches from agile and lean supply chain strategies (Mason-Jones, Naylor, \& Towill, 2000) to subsequently reap the advantages of both supply chains (Towill \& Christopher, 2002). 


\section{B. Supply Chain Practices}

Supply chain practices refer to all activities and processes performed by an organization to increase the efficiency and effectiveness of its internal supply chain (Ibrahim \& Hamid, 2014). They include both upstream and downstream members of the supply chain (Li et al., 2006). (Li et al., 2005, 2006, Sukati et al., 2011, 2012; Thatte, 2007) in their studies have depicted supply chain practices with regards to three dimensions i.e. Strategic supplier partnership, customer relationship, and information sharing. Our study is also done keeping in mind the same mentioned three dimensions of supply chain practices however we focus on only two dimensions i.e. supplier partnership management and customer management.

(Li et al., 2005, 2006; Monczka, Peterson, Handfield, \& Ragatz, 1998) define strategic supplier partnership as a longstanding relationship among a company and its suppliers which positively influences the strategic and operational capabilities of the participants providing them ongoing benefits. A strategic supplier partnership is one that has a positive influence on the supplier i.e. increases supplier's operational abilities and improves supplier's system, includes procurement and acquisition of products or services and ultimately enhances overall supply chain performance (Monczka et al., 1998; M. Q. Sufian, 2010).

Customer relationship management is the key and most critical component of a supply chain (Gharakhani \& Hamidi, 2012). Customer relationship includes all practices that are required to effectively build continuing and ongoing customer relations, manage customer queries or complaints and enhance customer satisfaction (Li et al., 2006). A company's customer relationship practices can facilitate organizational success and efforts leading to increase organizational performance (Ellram, 1991; Scott \& Westbrook, 1991; Turner, 1993).

\section{Supply Chain Performance}

To evaluate retail supply chain performance, as per (Beamon, 1999; Gunasekaran, Patel, \& Titiroglu, 2001; Ho, $\mathrm{Xu}, \&$ Dey, 2010) we have focused on performance of the supply chain in terms of is operations and specifically appraised it in terms of two dimensions i.e. responsiveness and efficiency. SCOR model and balanced SCOR model have also confirmed these two dimensions to be used to gauge the performance of a supply chain (Rana, Osman, Bahari, \& Solaiman, 2015).

How quickly and to what extent a supply chain can handle any deviations or variations in the customer's demand (Holweg, 2005; Lummus, Duclos, \& Vokurka, 2003; Prater, Biehl, \& Smith, 2001). Presently, customer demand is at its peak because of which timely delivery and availability of products or services is of great importance. This has generated peculiar need for volume flexible response (Vickery, Calantone, \& Droge, 1999). An organization whose supply chain responsiveness is high provides competitive advantage and in the long run has a progressive effect on the overall performance (Qureshi \& Compeau, 2009). Thus, organizations should adapt flexible and highly responsive supply chains to gain competitive advantage in this changing business environment (Moore \& S.M.R, 1996).
Supply chain efficiency can be defined in terms of supply chain performance, cost and a blend of the two (Ayers, 2006). When referring to supply chain performance, efficiency of a supply chain may refer to high customer satisfaction and timely delivery. Thus, organizations must be both cost centric and customer-focused. Furthermore, an efficient supply chain requires complete coordination and incorporation of all members within the supply chain network to minimize costs (Ayers, 2006).

H1: Supply Chain Strategies positively influences Retail Supply Chain Performance.

H2: Supply Chain Practices positively influences Retail Supply Chain Performance.

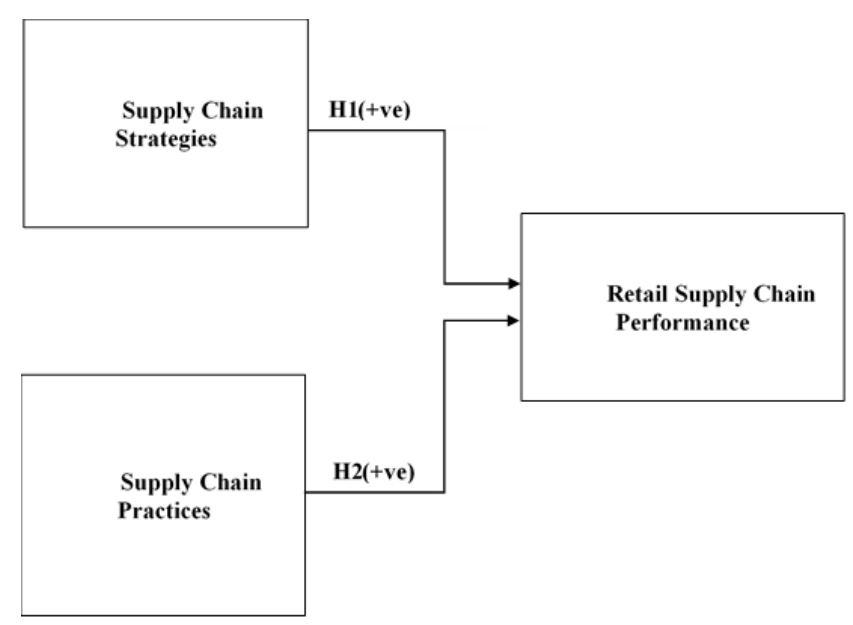

Source: (Ibrahim \& Hamid, 2014; Rana et al., 2015; Sukati et al., 2011)

\section{METHODOLOGY}

The sampling technique used was systematic random sampling. We prepared a list of one hundred and twenty (120) retail stores in Islamabad and gathered information from every second store. Thus, the sample size of the study was sixty (60) employees (lower to mid-level managers) working in the textile sector of Islamabad, Pakistan. Structured questionnaires were used for data gathering and collection. (Ambe, 2013) proposed reliable and valid instrument to measure supply chain strategies impact on supply chain performance. While, (Sukati et al., 2011) proposed reliable and valid instrument to measure supply chain practices impact on supply chain performance. A few selected sections of the above-mentioned text and proposed instruments have been adopted in this research.

We performed pilot test of thirty respondents from selected textile retail stores. The results of the test findings denoted reliability of all items within the range ( $\alpha=0.68$ to 0.789 ), showcasing that all variables under study have a high level of internal consistency (Nunnally, 1978; Peng, Schroeder, \& Shah, 2008).

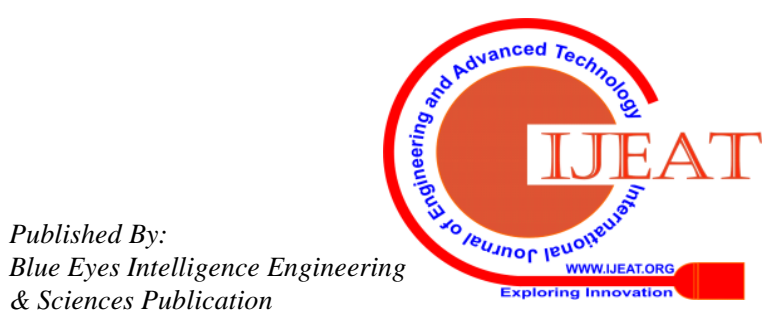




\section{RESULTS AND FINDINGS}

\section{A. Demographics Test}

Table-1: Demographics Test Results

\begin{tabular}{|c|c|}
\hline $\mathbf{N}$ & 60 \\
\hline \multicolumn{2}{|c|}{ Gender } \\
\hline & Frequency \\
\hline Male & 58 \\
\hline Female & 2 \\
\hline \multicolumn{2}{|c|}{ Education Level } \\
\hline College/Diploma & 17 \\
\hline Bachelor's Degree & 36 \\
\hline Masters & 7 \\
\hline PHD & 0 \\
\hline \multicolumn{2}{|c|}{ Category of Job } \\
\hline Management Level Top & 14 \\
\hline Middle & 46 \\
\hline Low & 0 \\
\hline \multicolumn{2}{|c|}{ Duration of Job } \\
\hline $1-5$ Years & 50 \\
\hline 6-10 Years & 7 \\
\hline 11-15 Years & 3 \\
\hline Over 15 Years & 0 \\
\hline
\end{tabular}

From above table it can be observed that:

- For Gender variable, we had a response of $96.7 \%(n=58)$ males and $3.3 \%(n=2)$ females of the total respondents $(n=60)$.

- For Education Level variable, we had a response of $28.3 \%(\mathrm{n}=17)$ from College/diploma respondents, $60 \%(n=36)$ from Bachelor's degree respondents, $11.7 \%(n=7)$ from Master's degree respondents and $0 \% \quad(n=0)$ from PHD respondents of the total respondents $(n=60)$.

- For Category of Job variable, we had a response of $23.3 \% \quad(n=14)$ from Management level top respondents, $76.7 \% \quad(\mathrm{n}=46)$ from Middle level respondents, $0 \%(n=0)$ from Low level respondents of the total respondents $(n=60)$.

- For Duration of Job variable, we had a response of $83.3 \%(n=50)$ from respondents with the organization for 1 to 5 years, $11.7 \%(n=7)$ from respondents with the organization for 6 to 10 years, $5 \%(n=3)$ from respondents with the organization for 11 to 15 years, and $0 \%(n=0)$ from respondents with the organization for over 15 years, of the total respondents $(n=60)$.

\section{B. Descriptive Statistics Test}

Table-2: Descriptive Statistics Test Results

\begin{tabular}{lccccc}
\hline & $\mathbf{N}$ & Mean & $\begin{array}{c}\text { Std. } \\
\text { Deviation }\end{array}$ & $\begin{array}{c}\text { Skewn } \\
\text { ess }\end{array}$ & $\begin{array}{c}\text { Kurtosi } \\
\text { s }\end{array}$ \\
\cline { 2 - 6 } & $\begin{array}{c}\text { Statist } \\
\text { ic }\end{array}$ & $\begin{array}{c}\text { Statist } \\
\text { ic }\end{array}$ & Statistic & $\begin{array}{c}\text { Statist } \\
\text { ic }\end{array}$ & $\begin{array}{c}\text { Statisti } \\
\text { c }\end{array}$ \\
STR & 60 & 3.1885 & .55514 & -.457 & 2.551 \\
PCT & 59 & 3.6356 & .64588 & -.869 & 2.730 \\
PER & 60 & 3.6000 & .68316 & -.608 & 1.598 \\
Valid N & 59 & & & & \\
(listwise) & 59 & & & & \\
\hline
\end{tabular}

As apparent it is observed that the mean value is more than 3. The standard deviations are less meaning there is not much deviation from the mean values. The data is skewed since the value of skewness showed fall between -1 to +1 . Kurtosis value should fall between -3 to +3 , and the results of descriptive statistics fall between these values.

\section{Reliability Test}

Table-3: Reliability Tests Results

\begin{tabular}{ccc}
\hline Variable & $\begin{array}{c}\text { Number } \\
\text { of items }\end{array}$ & $\begin{array}{c}\text { Cronbach } \\
\text { Alpha }\end{array}$ \\
\hline STR & 13 & .748 \\
PCT & 10 & .815 \\
PER & 9 & .798 \\
\hline
\end{tabular}

As apparent from the table above, supply chain strategies consisted of thirteen (13) items with calculated Cronbach's alpha value 0.748 (i.e. $\alpha=0.748$ ), supply chain practices consisted of ten (10) items with calculated Cronbach's alpha value $0.815(\alpha=0.815)$ and retail supply chain performance consisted of nine (09) items with calculated Cronbach's alpha value $0.798(\alpha=0.798)$.

It is observed that, Cronbach's alpha values for all values are greater than 0.7 . Therefore, the instrument was deemed reliable for data collection.

\section{Correlations Test}

\begin{tabular}{cccc}
\multicolumn{4}{c}{ Table-4: Correlation Tests Results } \\
\hline STR & 1 & PCT & PER \\
PCT & $.594^{* *}$ & $.486^{* *}$ \\
PER & $.486^{* *}$ & $.606^{* *}$ & $.606^{* *}$ \\
\end{tabular}

As per Pearson correlation, all the variables in the study are positively correlated and significant. Retail supply chain performance has moderate to strong correlation with supply chain management practices $(r=0.606, p<0.05)$ and weak to moderate correlation with supply chain management strategies $\quad(r=0.486, \quad p<0.05)$. While, supply chain management practices have moderate correlation with supply chain management strategies $(r=0.594, \mathrm{p}<0.05)$.

Although the correlations among the variables range from moderately weak to moderately strong, however the positive and significance correlations show the variables are in fact associated and have proportionality among them. So, if one variable increases the other may also increase.

\section{E. Regression Tests}

The hypotheses ( $\mathrm{H} 1$ and $\mathrm{H} 2$ ) state that supply chain management strategies and supply chain management practices are positively associated with retail supply chain performance.

The value of $\mathrm{R}$-square $(\mathrm{R} 2=0.391)$ shows that the variation in the dependent variable retail supply chain performance because of the independent variables supply chain strategies and practices is $39.1 \%$.

As per the performed F-test to 
check the model fitness, it has been observed that the model was fit for regression with significance value less than 0.05 $(\mathrm{F}=17.949, \mathrm{p}<0.05)$.

The beta (B) is the rate of change between the variables. The beta calculated between supply chain strategies and retail supply chain performance $(B=0.235)$ shows that with one unit change in supply chain strategies will cause 0.235 units change in retail supply chain performance. The beta between supply chain practices and retail supply chain performance $(B=0.523)$ shows that with one unit change in supply chain practices will cause 0.523 units change in retail supply chain performance.

The results for $\mathrm{t}$-test of $\mathrm{H} 2(\mathrm{t}=3.796, \mathrm{p}<0.05)$ shows that the $\mathrm{t}$-value is significant. Thus, our hypothesis is valid and accepted. This also shows that there exists a positive relationship between supply chain practices and retail supply chain performance. However, the results for t-test of $\mathrm{H} 1$ $(\mathrm{t}=1.474, \mathrm{p}<0.05)$ shows that the $\mathrm{t}$-value is insignificant and therefore, the hypothesis is rejected.

Table- 5: Multiple Regression Test Result

\begin{tabular}{|c|c|c|c|c|c|c|c|}
\hline Hypothesis & IV & DV & $\mathbf{R}^{2}$ & B & t-test & F-test & Sig. \\
\hline $\begin{array}{l}\text { H1: Supply Chain Strategy positively influences the } \\
\text { Retail Supply Chain Performance. }\end{array}$ & STR & PER & \multirow{2}{*}{0.391} & 0.235 & 1.474 & \multirow{2}{*}{17.949} & \multirow{2}{*}{0.00} \\
\hline $\begin{array}{l}\text { H2: Supply Chain Practices positively influences Retail } \\
\text { Supply Chain Performance. }\end{array}$ & PCT & PER & & 0.523 & 3.796 & & \\
\hline
\end{tabular}

\section{F. Discussion of Results}

Within this research we had proposed two hypotheses i.e. H1: Supply chain strategies have a positive impact on retail supply chain performance (Rana et al., 2015). However, our findings were unable to prove this hypothesis. Thus, it has been rejected. We would like to add that this is a relatively new theory observed by (Rana et al., 2015); although literature with regards to the manufacturing industry does exist, research in retail supply chain is very scarce (Rana et al., 2015) and specifically textile industry is even more so.

$\mathrm{H} 2$ : Supply chain practices have a positive impact on retail supply chain performance. Proven by our findings and previous literature, this proposed hypothesis has been accepted. (Sukati et al., 2011) states that supply chain practices do have positive impact on supply chain performance and better supply chain practices do lead to responsiveness and competitive advantage. However, our research was limited to the consumer good industry.

We would like to highlight an interesting fact observed during analysis. Although we were unable to support our hypothesis (i.e. H1: supply chain strategies have a positive impact on retail supply chain performance) with findings, we observed that supply chain management strategies are moderate to strongly associated with supply chain management practices. We would like to suggest this association be further investigated.

\section{Conclusion}

According to the results of this research, retail supply chain performance is affected by supply chain practices but not supply chain strategies. There can be several reasons behind the lack of evidence to support our first hypothesis, i.e. research was limited to only two independent variables and did not take into account other factors, lack of literature, economic conditions, limited scope of research, textile sector is a relatively new and developing sector in Pakistan, list of textile retailers was not conclusive, approaches and methodologies of the textile outlets may not be disclosed to the respondents, inaccurate and biased responses to self-reporting questionnaire. Thus, we recommend that detail

and thorough research be conducted to find conclusive evidence before completely rejecting this hypothesis.

As enough evidence was found to indicate that supply chain practices do affect retail supply chain performance thus, in order to enhance performance of the retail supply chain managers should implement supply chain practices aligned with organizational strategies and goals to increase over-all supply chain performance. Supply chain management strategies must be designed in a manner that it is effectively applied into supply chain management practices (Sufian, 2010). Moreover, such strategies and practices derived by the top management must evolve and emerge in the organizational practices as well.

Lastly, we observed in our research, supply chain management strategies are related with supply chain management practices and have a positive impact on them. We would like to suggest this association be further investigated.

\section{REFERENCES}

1. Ambe, I. M. (2013). Determining supply chain practices and strategies of light vehicle manufacturers in South Africa. UNIVERSITY OF SOUTH AFRICA.

2. Ayers, J. B. (2006). Handbook of supply chain management. Boca Raton, Fl: Auerbach. Barki,H. and Hartwick,J. "Measuring User Participation, User Improvement, and User Attitude.” MIS Quarterly, $18(1), 59-82$.

3. Beamon, B. M. (1999). Measuring supply chain performance. International Journal of Operations \& Production Management, 19(3), 275-292.

4. Blome, C., Eckstein, D., \& Schoenherr, T. (2013). The Impact of knowledge transfer and complexity on supply chain felxibility: A knowledge-based view. International Journal of Production Economics, 147.

5. Bommer, M., O’Neil, B., \& Treat, S. (2001). Strategic Assessment of the Supply Chain Interface: a Beverage Industry Case Study. International Journal of Physical Distribution and Logistics Management, 31(1), 11-25.

6. Braunscheidel, M. ., \& Suresh, N. . (2009). The Organizational Antecedents of a Firms's Supply Chain Agility for Risk Mitigation and Response. Journal of Operations Management, 27(2), 119-140. 
7. Bruce, M., Daly, L., \& Towers, N. (2004). A solution for supply chain management in the textiles and clothing industry. International Journal of Operations and Production Management, 24(2), 151-170.

8. Chen, I., \& Paulraj, A. (2004). Towards a theory of supply chain management: the onstructs and measurements. Journal of Operations Management, 22, 119-150.

9. Chin, W. ., Chopra, S., \& Meindl, P. (2010). The partial least squares approach for structural equation modeling (1998). In Supply Chain Management: Strategy, planning and operations. Boston Pearson.

10. Chopra, S., \& Meindl, P. (2007). Supply Chain Management: Strategy, Planning \& Organization (3rd Edition). NJ: Prentice Hall Inc.

11. Chow, S. W., Christian N., M., Chu-Hua, K., Min H., L., Chinho, L., \& Hojung, T. (2008). Supply chain management in the US and Taiwan. International Journal of Management Science, Omega, 36, 665-679.

12. Christopher, M. (1998). Logistics and Supply chain management strategies for Reducing costs and improving services (2nd Edition) Pitman, London

13. Christopher, M. (2003). Creating agile supply chains, in J.L. Gattorna (ed). Gower Handbook of Supply Chain Management. Burlington, V.T: Gower, 283-295.

14. Christopher, M., \& Peck, H. (2004). Building the Rsilient Supply Chain. Internation Journal of Logistics Management, 15(2), 1-13.

15. Christopher, M., \& Towill, D. (2001). An integrated model for the design of agile supply chain. Internation Journal of Physical Distribution and Logistics Management., 31(4), 235-246.

16. Cohen, S., \& Roussel, J. (2005). Strategic Supply Chain Management: The Five Disciplines for Top Performance. New York: McGraw-Hill.

17. Cooper, D., \& Schindler, P. (2001). Business Research Methods (7th Edition). McGraw-Hill/Irwin, New York.

18. Croxton, K., Garcia-Dastugue, S., \& Lambert, D. (2001). The Supply chain Management Process. Internation Journal of Logistics Management, 12(2), 13-36.

19. Donlon, J. P. (1996). Maximizing value in the supply chain, Chief Executive, 117, 54-63.

20. Ellram, L. M. (1991). Supply Chain Management: The Industrial Organization Perspective. International Journal of Physical Distribution and Logistics Management, 21(1), 13-22.

21. Fisher. (1997a). What is the Right Supply Chain for your Product? Harvard Business Review, 75(2), 105-116.

22. Fisher, M. . (1997b). What is the Right Supply Chain for Your Product? Harvard Business Review, 75(2), 105-116.

23. Germain, R. (1989). Output Standardization and Logistical Strategy, structure and Performance. Internation Journal of Physical Distribution and Logistics Management, 19(1), 21-29.

24. Gerwin, D. (1987). An Agenda for Research on the Flexibility of Manufacturing Processes. International Journal of Operations \& Production Management, 7(1), 38-49.

25. Gharakhani, D. R. K. M., \& Hamidi, N. (2012). Impact of supply chain management practices on innovation and organizational performance in Iranian. African Journal of Business Management, 6(19), 5939-5949.

26. Green, J., K., W., Whitten, D., \& Inman, R. A. (2008). The impact of logistics performance on organizational performance in a supply chain context. Supply Chain Management, 13(4), 317-327.

27. Gunasekaran, A., Patel, C., \& Titiroglu, E. (2001). Performance Measures and Metrics in a Supply Chain Environment. International Journal of Operations \& Production Management, 21(1/2), 71-87.

28. Hair, J. ., Black, W. ., Babin, B. ., \& Anderson R.E. (2010). Multivariate Data Analysis (Seventh Edition). Prentice Hall, Upper Saddle River, New Jersey.

29. Hanson, J. D., Melynk, S. A., \& Calantonr, R. A. (2011). Defining and Measuring Allignment in Performance Management. International Journal of Operations and Production Management, 31(10), 1089-1114.

30. Hines, T. (2004). Supply Chain Strategies: Customer-driven and customer-focused. Boston: Elsevier.

31. Ho, W., Xu, X., \& Dey, P. . (2010). Multi-criteria decison making approaches for supplier evaluation and selection: a literature review. European Journal of Operational Research, 202, 16-24.

32. Holweg, M. (2005). An Investigation Into Supplier Responsiveness. International Journal of Logistics Management, 16(1), 96-911.

33. Hsu, C. ., Tan, K. ., Laosirihongthong, T., \& Leong, G. . (2011). Entrepreneurial SCM competence and performance of manufacturing SME's. International Journal of Production Research, 49(22), 6629-6649.

34. Ibrahim, S. D., \& Hamid, A. A. (2014). Supply Chain Management Practices and Supply Chain Performance Effectiveness. International Journal of Science and Research, 3(8).

35. Jacobs, F. ., \& Chase, R. . (2008). Operations and supply chain management: the core. Boston: McGraw Hill.

36. Kazi, A.-U.-Z., \& Nazmul Ahsan, A. M. M. (2014). Lean supply chain performance management. Internation Journal of Productivity and Performance Management, 63(5), 588-612.

37. Koh, S. C., Demirbag, M., Bayraktar, E., Tatagolu, E., \& Zaim, S. (2007). The impact of supply chain management practices on performance of SMEs. Industrial Management and Data Systems, 107(1), 103-124.

38. Lee, H. (2002a). Aligning supply chain startegies with products uncertainties. California Managemet Review Reprint Series, University of California., 44(3).

39. Lee, H. (2002b). Aligning supply chain strategies with products uncertainities. California Management Review Reprint Series, 44(3).

40. Lee, H. (2004). A triple-A supply chain. Harvard Business Review, 82(10), 102-112.

41. Lee, H. L. (2004). The Triple-A Supply Chain. Harvard Business Review, 82(10), 102-112.

42. Lewicka, D. (2011). Creating Innovative Attitudes in an Organisation Comparative Analysis of Tools Applied in IBM Poland and ZPAS Group. Journal of Asia Pacific Business Innovation and Technology Management, 1(1), 1-12.

43. Li, S., Ragu-Nathan, T. S., Ragu-Nathan, B., \& Rao, S. S. (2005). Development and Validation of a measurement instrument for studying supply chain management practices. Journal of Operations Management, 23(6), 618-641.

44. Li, S., Ragu-Nathan, T. S., Ragu-Nathan, B., \& Rao, S. S. (2006). The impact of supply chain management practices on competitive advantage and and organizational performance. International Journal of Management Science, Omega, 34(2), 107-124.

45. Lummus, R. ., Duclos, L. ., \& Vokurka, R. . (2003). Supply Chain Flexibility: Building a New Model. Global Journal of Flexibility Systems Management, 4(4), 1-13.

46. Margrette, J. (1998). The Power of Virtual Integration: An Interview with Dell Computers' Michael Dell. Harvard Business Review, 76(2), 72-84.

47. Mason Jones, R., Naylor, B., \& Towill, D. R. (2000). Lean, Agile or Leagile? Matching your supply chain to the marketplace. International Journal of Production Research, 38, 4061-4070.

48. Mason-Jones, R., Naylor, B., \& Towill, D. (2000). Lean, Agile and Leagile: Matching your supply chain to the marketplace. International Journal of Production Research, 38(17), 4061-70.

49. Min, S., \& Mintzer, J. (2004). Developing and measuring supply chain management concepts. Journal of Business Logistics, 25(1), 63-92.

50. Moberg, C. R., Cutler, B. D., Gross, A., \& Speh, T. W. (2002) Identifying Antecedents of Information Exchange Within Supply Chains. International Journal of Physical Distribution and Logistics Management, 32(9), 755-770.

51. Monczka, R. M., Peterson, K. J., Handfield, R. B., \& Ragatz, G. L. (1998). Success factors in strategic supplier alliances: The buying company perspective. Decision Sciences, 29(3), 553-577.

52. Moore, J., \& S.M.R. (1996). Agility is Easy; But Effective Agile Manfacturing is not. IEE Colloquium (Digest), 179, 4

53. Narasimhan, R., \& Das, A. (1999). Manufacturing agility and supply chain management practices. Production and Inventory Management Journal, 40(1), 4-10.

54. Narasimhan, R., Kim, S. ., \& Tan, K. . (2008). An empirical investigation of supply chain strategy typologies and relationships to performance. International Journal of Production Research, 46(18) $1-29$

55. Naylor, B., Naim, M. ., \& Berry, D. (1999). Leagility: Integrating the lean and agile manufacturing paradigms in the total supply chain International Journal of Production Economics, 62(1-2), 107-118.

56. Nunnally, J. C. (1978). Psychometric Theory (2nd Edition). Nw York: McGraw Hill.

57. Peng, D. ., Schroeder, R. G., \& Shah, R. (2008). Linking routines to operations capabilities: A new perspective. Journal of Operations Management, 26(6), 730-748.

58. Pereira-Molina, J., Claver-Cortes, E., Molina-Azorin, J. F., \& Tari, J. J. (2012). Quality Management, environmental management and firm performance direct and mediating effects in the hotel industry. Journal of Cleaner Productions, 37, 82-92.

59. Perry, M. (1996). Talk at the Marketing Council, London.

60. Prater, E., Biehl, M., \& Smith, M. . (2001). International Supply Chain Agility. International Journal of Operations and Production Management, 21(5-6), 823-840. 
61. Qi, Y., Boyer, K. ., \& Zhao, X. (2009). Supply chain strategy, product characteristics and performance impact: evidence from Chinese Manufacturers. Decison Sciences, 40(4), 667-695.

62. Qi, Y., Zhao, X., \& Sheu, C. (2011). The impact of competitive strategy and supply chain startegy on business performance: The role of environmental uncertainty. Decision Sciences, 42(2), 371-389.

63. Qureshi, I., \& Compeau, D. (2009). Assessing between group differences in information systems research: a comparison of covariance and component based sem. MIS Quarterly, 33(1), 197-214.

64. Radas, S., \& Bozic, L. (2009). The antecendents of SME innovativeness in an emerging transition economy. Technovation, 29, 438-450.

65. Rana, S. M., Osman, A., Bahari, A. B., \& Solaiman, M. (2015). DETERMINANTS OF SUPPLY CHAIN PERFORMANCE: A STRATEGIC POINT OF VIEW. International Journal of Supply Chain Management, 4(3).

66. Randall, T., \& Ulrich, K. (2001). Product variety, Supply chain structure and Firm performance: Analysis of the U.S Bicycle Industry. Management Sciences, 47(12), 1588-1604.

67. Randall, W. ., Gibson, B. ., Defee, C. ., \& Williams, B. . (2011). Retail Supply chain management: key priorities and practices. Internation Journal of Logistics Management, 22(3), 390-402.

68. Sadler, I. (2007). Logistics and supply chain integrations. Sage Publications.

69. Scott, C., \& Westbrook, R. (1991). New Strategic Tools for Supply Chain Management. International Journal of Physical Distribution and Logistics, 21(1), 23-33.

70. Seuring, S., Goldbach, M., Schneidewind, U., \& Muller, M. (2003). Strategic supply chain management from focused factories to focused supply chain. Strategy and Organization in Supply Chains, 181-196.

71. Shah, R., \& Goldstein, S. . (2006). Use of structural equation modeling in operations management research: looking back and forward. Journal of Operations Management, 24(2), 148-169.

72. Simchi-Levy, D., Kaminsly, P., \& Edith, S.-L. (2000). Desigining and managing a supply chain. New York: Irwin McGraw Hill.

73. Sufian, M. Q. (2010). Alignmnet of of Information Systems with Supply Chains: Impacts of Supply Chain Performance and Organizational Performance. University of Toronto.

74. Sufian, Q. M. T. (2013). Lean and agile supply chain strategies and supply chain responsiveness: the role of strategic supplier partnership and postponement. Supply Chain Management: An International Journal, 18(6), 571-582.

75. Sukati, I., Hamid, A. B. A., Baharun, R., Tat, H. H., \& Said, F. (2011). A study of supply chain management practices: An empirical investigation on consumer goods industry in Malaysia. International Journal of Business and Social Science, 2(17), 166-176.

76. Sukati, I., Hamid, A. B., Baharun, R., \& Yusoff, R. M. (2012). The study of supply chain management strategy and practices on supply chain performance. Procedia-Social and Behavioral Sciences, 40, 225-233.

77. Swafford, P. ., Ghosh, S., \& Murthy, N. (2005). The antecedents of supply chain agility of a firm: scale development and model testing. Journal of Operations Management, 24, 170-188.

78. Tan, K. ., Layman, S. ., \& Wisner, J. . (2002). Suppy chain management: A strategic perspective. International Journal of Operations and Production Management, 22(6), 614-631.

79. Tan, K. C., Kannan, V. R., \& Handfield, R. B. (1998). Supply Chain Management: Supplier performance and firm performance. International Journal of Purchasing and Materials Management, 34(3), 2-9.

80. Tan, K. C., Lyman, S. B., \& Wisner, J. D. (2002). Supply Chain Management: A Strategic Perspective. International Journal of Operations and Production Management, 22(6), 614-631.

81. Tang, M., \& Gattorna, J. . (2003). Developing and alligned supply chain strategy in J.L Gattorna (ed). Gower Handbook of Supply Chain Management, 25-35.

82. Thatte, A. A. (2007). Competitive advantage of a firm through supply chain responsiveness and SCM practices. University of Toledo.

83. Towill, D., \& Christopher, M. (2002). The supply chain strategy conundrum: To be lean or agile or to be lean and agile? International Journal of Logistics: Research and Applications, 5(3), 299-309.

84. Tseng, M. L. (2010). An assessment of causes and effect of decision making model for firm environmental knowledge management capacities in uncertainty. Environmental Monitoring and Assessment.

85. Turner, J. R. (1993). Integrated Supply Chain Management: What's Wrong With This Picture? Industrial Engineering, 25(12), 52-55.

86. Vickery, S., Calantone, R., \& Droge, C. (1999). Supply Chain Flexibility: an empirical study. The Journal of Supply Chain Management, 35(3), 16-24.

87. Vitasek, K., Manrodt, K. ., \& Abbott, J. (2005). What makes a lean supply chain? Supply Chain Management Review, 9(7), 39-45.

88. Vonderembse, M. A., Uppal, M., Huang, S. H., \& Dismukes, J. P. (2006). Designing supply chains: Towards theory development. International Journal of Production Economics, 100(2), 223-238.

89. Ward, P., Mccreery, J., Ritzman, L., \& Shamia, D. (1998). Competetive Priorities in Operations Management. Journal of Operations Management, 29(4), 1035-1046.

90. Wiese, A., Kellner, J., Toporowski, W., \& Zielke, S. (2012). Sustainability in retailing a summative content analysis. International Journal of Retail \& Distribution Management, 40(4), 318-335.

91. Wines, L. (1996). High Order Strategy for Manufacturing. The Journal of Business Strategy, 17(4), 32-33.

92. Wisner, J. ., \& Tan, K. . (2005). Principals of Supply chain management, A balanced approach. Rental Plan, Commodity Logistics.

93. Wisner, J. D. (2003). A structural equation model of supply chain management strategies and firm performance. Journal of Business Logistics, 24(1), 1-26.

94. Wong, C. Y., Arlbjorn, J. S., \& Johansen, J. (2005). Supply chain management practices in toy supply chains. Supply Chain Management: An International Journal, 10(5), 367-378.

95. Zhou, H., \& Benton, W. C. (2007). Supply chain management practices and information sharing. Journal of Operations Management, 25(6), 1348-1365.

\section{AUTHORS PROFILE}

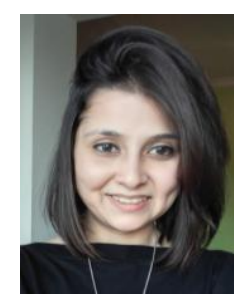

Ms. Mehwish Naeem, obtained Bachelor's in Software Engineering from Bahria University in 2008. Master's in Business Administration from SZABIST University, Major Human Resource with Minor in Supply Chain in 2017. Ms. Naeem works at IdeasUnlimited as an Operations Manager, a US based Global Business Support and Solutions Provider based out of Sugarland, Texas.

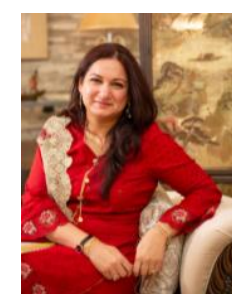

Dr. Iram Tahir, PhD, Associate CIPD, $\mathrm{PhD}$ Public Administration, University of Karachi, Pakistan. Dr. Tahir has 5 years teaching experience from 10 leading universities in Pakistan; 7 years of research consultancy experience in UK with 400 research projects; 2 years of business training experience in Pakistan. Her Publications include but are not limited to:

1. 'Women Empowerment through Political Participation in Pakistan Obstacles and Opportunities'. PhD Dissertation submitted to Department of Public Administration, University of Karachi, Pakistan, for final review for award of PhD degree.

2. 'Terrorism, Human Rights Dilemma and its Effects on Women in Swat, Pakistan', Pakistan Journal of Gender Studies, Vol. 17 (September 2018), pp. 39-54.

3. 'Factors Influencing Counterproductive Work Behaviour In Pakistani Organisations', ISSRA PAPERS, Vol X(1), pp. 143-159.

4. Brand Self Congruence and Brand Preference: A Study of Mobile Phone Users in Pakistan', The Business and Management Review, Vol. 10 (1), pp. 92- 100.

5. Work-Life Conflict and Organizational Commitment: A Study of Female Faculty in Higher Education, Pakistan Journal of Gender Studies, Vol. 19 (September 2019), pp. 196-216.

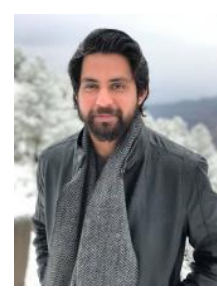

Mr. Zain Iqbal holds Master's in Business Administration from SZABIST University, Major Finance with Minor in Supply Chain (2017), Bachelor's in Arts from Allama Iqbal Open University (2013), Certified Accountant Technician from ACCA, U.K (2011). Mr. Iqbal is working as a Business Analyst II, leading a team of 20 of the Technology Department, at S\&P Global Market Intelligence, a subsidiary of S\&P Global Inc an American publicly traded corporation headquartered in Manhattan, New York City.

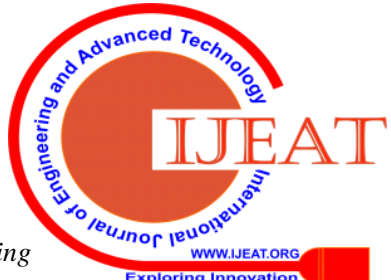




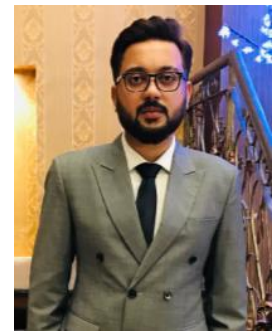

Mr. Hassaan Shafique, holds Master's in Business Administration from SZABIST, Major Supply Chain with Minor Finance (2017), Bachelor's in Arts from Punjab University (2014). Mr. Shafique works as Regional Sales Head in Imperial Electric Company, leading OEM of Diesel Generating Sets that represents renowned manufacturers

i.e. Schneider Electric, Thorn Lighting, Ferraz Yotai Refractories and Foster Wheeler. 